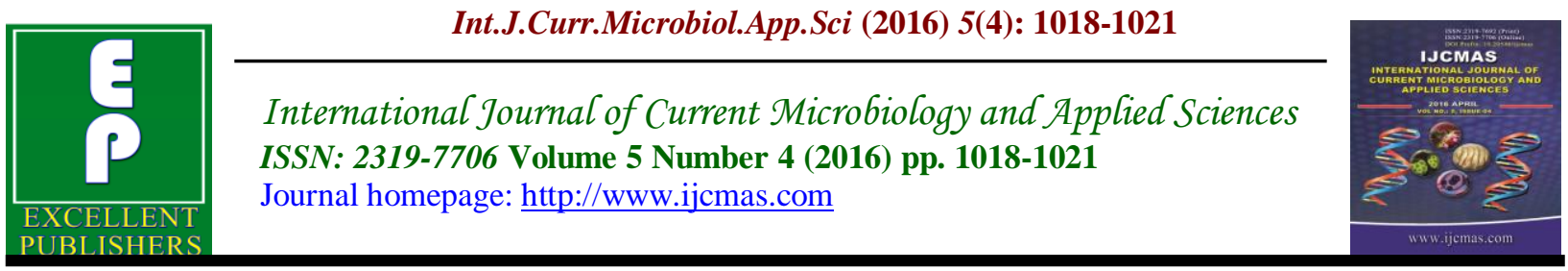

Review Article

http://dx.doi.org/10.20546/ijcmas.2016.504.116

\title{
Need to facilitate Farmers for Quality Assurance of Biofertilizers in India
}

\author{
Shweta Yadav* \\ Department of Zoology, Dr H S Gour Vishwavidalaya \\ (A Central University), Sagar-470003, MP, India \\ *Corresponding author
}

\begin{abstract}
A B S T R A C T
Keywords

Quality Assurance of Biofertilizers, facilitate farmers, IEC cell, Sale-purchase counter

Article Info

Accepted:

22 March 2016

Available Online:

10 April 2016

Unlike chemical fertilizer, there is no organized market mechanism for biofertilizers. Presently, small scale farmers of India are producing biofertilizers to meet their own demand and selling the surplus produce through sale/purchase counters in villages. However, in view of growing demand of biofertilizers in recent years some big farmers and entrepreneurs have shown much interest and set-up their own business to produce biofertilizers on mass scale. They in turn are selling their produce through retailers. However, there is no check or quality assurance of their product by any authentic or professional agency. It is at this stage there is a need for standardization and quality control measures for production of quality biofertilizers and also to fetch high-price. The present article emphasized to develop professional facility for testing biofertilizer (BF) and advice to improve its quality for nutrient enrichment, ma ybe a new initiative and step forward in this direction.
\end{abstract}

\section{Introduction}

The growing health awareness and fears of fertilizers and pesticides contamination have given a new momentum to organic farming in India and abroad. The organic farming in India is catching-up fast especially for export, valued at Rs. 100 crore. Organically produced items like tea, coffee, spices, fruits, vegetables, pulses, cereals and oil seeds are getting higher demand from developed countries like USA, UK and Japan. Total market potential for organic foods in India is estimated at Rs. 2300 crore. The current market value of organic demand is estimated at Rs. 1450 crore. The present growth rate in domestic organic market is 35 per cent, and it is anticipated to grow by 50 per cent by 2020 . The potential share of organic produce in domestic market is 5-6 per cent at present, and area under organic cultivation in India is around 2.5 million hectare.

Recognizing the fact that organic produce is fetching remunerative price and demand for such products have increased many-fold, a good number of farmers have come forward 
to take-up organic agriculture for their traditional crops in Western U.P. In this endeavor with support of Government of India, author initiated with a programme of providing first-hand knowledge, training and technical expertise to farmers \& field demonstration on vermitechnology in different districts of Western U.P. Some 6672 farmers have so far been trained and 1810 Vermicompost Units have been set-up at farmers fields through the transfer of technology under "Lab to land" programme. The production of biofertilizer by small \& medium farmers is now a ground reality and catching-up day by day, particularly by weaker sections of society as employment avenue in rural sector.

The present News Report in a prestigious daily (AMAR UJALA Dated 04.01.2010) is alarming and eye-opener. This immediately calls for the attention of scientists to go for quality assurance of biofertilizers including the vermicompost, before its marketing so that consumers/farmers are saved from heavy losses as indicated in this report.
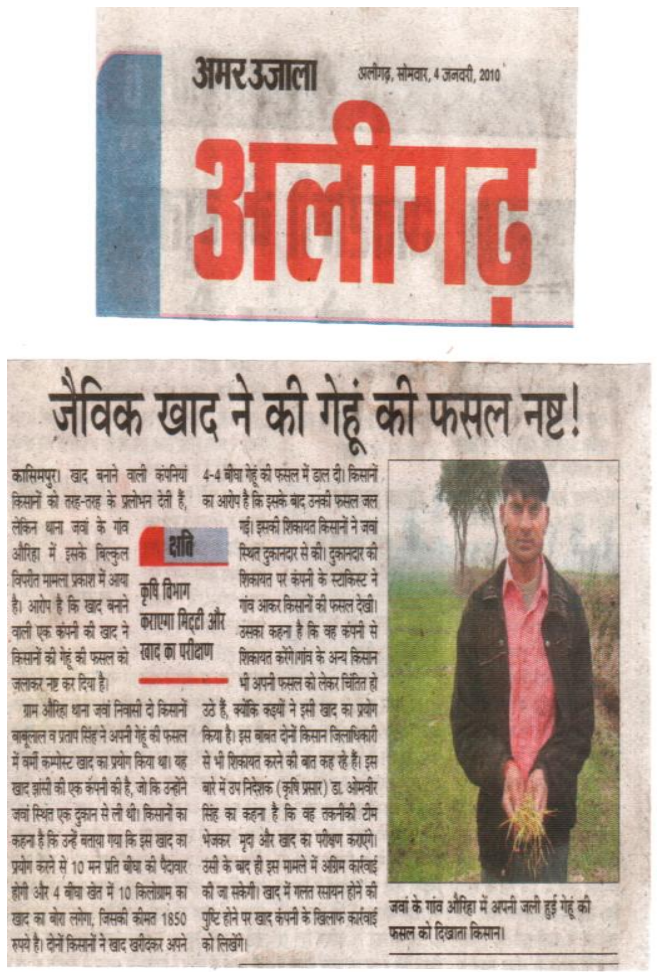

There is a need to develop Information, Education and Communication (IEC) cell for farmers to address their day-to-day problems related to Quality Assurance, Production \& Marketing of biofertilizers (including Vermicompost). There appears no professional facility for testing biofertilizers in India. However, a literature search indicates that USA alone has takenup this programme in consumers \& farmers interest. The Cornell Waste Management Institute, USA has set-up a Agricultural Analytical Service Laboratory for manure testing at the Pennsylvania State University for compost analysis with Cooperative extension offices.

\section{Importance and Need of IEC in India}

Biofertilizer contains major and minor nutrients in plant-available forms, enzymes, vitamins and plant growth hormones. Vermicompost has a more beneficial impact on plants than normal compost. Chemical analysis of the casts gives a good indication of changes directly caused by the worms. During composting nitrogen loss or denitrification is an indispensable phenomenon that affects the quality of vermicompost. As nitrogen percentage is very essential for fertilizer value or as soil conditioner, this has to be achieved in the composting process.

Composting testing is important for characterizing the beneficial physical and chemical properties of compost as well as for identifying potential problems with compost use. Therefore, compost analysis is necessary for the accurate determination of nutrient contents leading to optimum economic crop production. Besides testing for spurious or substandard manure, the results of these tests may help to evaluate a compost's quality as an agronomic or horticultural resource. Analytical Service 
Laboratory for manure testing at the Pennsylvania State University for compost analysis with Cooperative extension offices. It is in this context, the present proposal has been formulated.

Over the years huge quantity of vermicompost is being produced and marketed it in Western U.P. by farmers and entrepreneurs since over 6000 Vermicompost Units have been set-up alone in this area through continues efforts of author supported by Department of Biotechnology, Government of India. The IEC centre for quality assurance of biofertilizers may cater to the farmers in particular and other entrepreneurs in general of the various districts of country.

\section{Testing of Biofertilizers}

Testing of biofertilizer is very important because many a times composter wants information for consumers or for themselves and need to know the characteristics of a product before using it. These tests includes $\mathrm{pH}$, Electrical conductivity (soluble salts), Coarse fragments, Moisture content, Bulk density, Organic matter and Estimated Organic Carbon, Viable counts of particular microbe, Total Nitrogen, C:N Ratio, Nitrate and Ammonium levels, Nutrient Rating, Equivalent Base Cation percentage, Extractable micronutrients, Extractable heavy metals etc.

\section{Proposed Work-flow of IEC}

(a)To create awareness about need for quality-check of biofertilizers among farmers and consumers for optimum results and save them from use of substandard or spurious biofertilizers in view of the present News Report.

(b) Collection of 5 samples from the production units of farmers \& entrepreneurs to evaluate their quality and nutrient status.

(c)Testing the samples in lab for various parameters indicated above.

(d) Advising farmers/ producers of biofertilizers to improve quality by following correct methodology whenever needed.

(e)To fetch high-rate, with standard and enriched biofertilizer with quality certification, following SOP.

\section{Generation of enhanced Income}

Although market for biofertilizers in India is expending through sustained efforts of both State and Central Government initiatives, yet the producers/ farmers/ entrepreneurs get only marginal profit on its sale because there is no authentic mechanism/ facility available for them to get the product tested and quality is assured for its optimum nutrients. In Western U.P. with the continuous pains taking efforts of author over 6000 Vermicompost Units producing some 96 MT capacity have been set-up.

However, the farmers still get only marginal profit. The demand as well as price of biofertilizer will go high once the quality of produce is labeled as certified, thereby generating more income. The present article envisaged professionally testing of biofertilizers produced by farmers for its quality, may be a pioneer attempt in this direction.

\section{Acknowledgement}

We acknowledge the financial support of the Department of Biotechnology, Ministry of Science and Technology, Govt. of India, New Delhi, to carry out this study. 


\section{References}

Amar Ujala. 2010. News paper, Agra UP (Ed. Aligarh), India. Deteioration of wheat crop with application of biofertilizer dated 04.01.2010, $\mathrm{p} 9$.

Yadav Shweta, Singh, V.K. 2014. Vermitechnology: Rebuilding of
Sustainable Livelihoods. Nova Science Publisher, Inc: 400 Oser, Ave, Suite 1600: Hauppauge, New York 117883619 USA, ISBN: 978-1-6317-943-3. Yadav Shweta. 2014. Empowerment of Weaker Section of Society through Vermitechnol., LAP Lambert Academic Publishing, Germany.

\section{How to cite this article:}

Shweta Yadav. 2016. Need to facilitate Farmers for Quality Assurance of Biofertilizers in India. Int.J.Curr.Microbiol.App.Sci.5(1): 1018-1021. doi: http://dx.doi.org/10.20546/ijcmas.2016.504.116 